Journal of Health Science
(Jurnal Ilmu Kesehatan)
https://www.ejournalwiraraja.com/index.php/JIK
$2356-5284$ (Print) | 2356-5543 (online)

\title{
Gambaran Status Tekanan Darah Penderita Hipertensi di Desa Karanganyar Kecamatan Kalianget Kabupaten Sumenep
}

\author{
Emdat Suprayitno ${ }^{1}$, Cory Nelia Damayanti ${ }^{2}$, Mujib Hannan $^{3}$ \\ ${ }^{1}$ Program Studi Profesi Ners Universitas Wiraraja \\ ${ }^{2,3}$ Program Studi Keperawatan Universitas Wiraraja \\ 1'emdat@wiraraja.ac.id, ${ }^{2}$ corynelia@wiraraja.ac.id, ${ }^{3}$ mujib@wiraraja.ac.id
}

\begin{tabular}{ll}
\hline Informasi artikel & ABSTRAK \\
\hline Sejarah artikel: & Penyakit hipertensi adalah salah satu masalah kesehatan di dunia yang juga \\
Diterima:10-11-2019 & disebut sebagai the silent killer yaitu penyakit mematikan tanpa adanya \\
Publikasi:28-11-2019 & tanda dan gejalanya terlebih dahulu sebagai peringatan bahayanya. Status \\
& tekanan darah akan semakin tinggi seiring menurunnya fungsi organ tubuh.
\end{tabular}
Jenis penelitian ini adalah deskriptif kuantitatif dengan menggunakan design cross sectional non analitik. Teknik pengambilan sampel menggunakan total sampling dengan jumlah sampel 32 orang. Instrument yang digunakan

Kata kunci:

Tekanan Darah,

Hipertensi,

Penderita Hipertensi berupa alat tensimeter dan lembar observasi tekanan darah.

Hasil penilitan menunjukkan bahwa mayoritas responden berusia 55-60 tahun yaitu 10 orang $(31,25 \%)$, mayoritas responden berjenis kelamin lakilaki sebanyak 18 orang (56,25\%). Status tekanan darah pada penderita hipertensi di desa karanganyar adalah tekanan darah sistolik 140-159 mmHg, tekanan darah diastolic 90-99 mmHg sebanyak 18 orang (56,25\%)

Dapat disimpulkan bahwa mayoritas status tekanan darah penderita hipertensi di Dusun Gadung Desa Karanganyar Kecamatan kalianget adalah kategori Hipertensi Derajat I.

Key word: Blood Pressure, Hypertension, Patients with Hypertension,

\section{ABSTRACT}

Hypertension is one of the health problems in the world which is also referred to as the silent killer, which is a deadly disease without any signs and symptoms beforehand as a warning of its dangers. The status of blood pressure will get higher as the function of the body's organs decreases.

This type of research is quantitative descriptive using non-analytic cross sectional design. The sampling technique uses total sampling with a sample size of 32 people. The instrument used in the form of a tensimeter and blood pressure observation sheet.

The results showed that the majority of respondents aged 55-60 years were 10 people (31.25\%), the majority of respondents were male as many as 18 people (56.25\%). Blood pressure status in patients with hypertension in Karanganyar Village is systolic blood pressure 140-159 $\mathrm{mmHg}$, diastolic blood pressure $90-99 \mathrm{mmHg}$ as many as 18 people $(56.25 \%)$

It can be concluded that the majority of blood pressure status of hypertension sufferers in Gadung Hamlet, Karanganyar Village, Kalianget Subdistrict are in the category of Hypertension.

\begin{abstract}
Pendahuluan
Hipertensi menjadi masalah kesehatan dengan morbiditas dan mortalitasnya yang tinggi. Badan Kesehatan Dunia (WHO) menyatakan Pada tahun 2025 diproyeksikan sekitar 29 persen warga dunia terkena hipertensi, the silent killer adalah istilah tepat bagi penyakit hipertensi karena penyakit ini tanpa memberikan gejala dan keluhan dan jarang penderitanya menyadari penyakit ini (Karo SK, 2012).
\end{abstract}

Berdasarkan hasil studi pendahuluan kepada 5 warga desa karanganyar didapatkan data bahwa 3 orang menderita penyakit hipertensi dan mereka mengatakan tidak mengetahui secara jelas tentang penyakit hipertensi dan cara perawatan keluarga dengan hipertensi dirumah, mereka mengatakan hanya berobat dan memeriksakan kesehatan jika terdapat gejala penyerta seperti pusing. 
Riskesdas 2007 menjelaskan penyakit hipertensi menempati peringkat ke tiga (3) setelah stroke dan tuberculosis (Rahajeng, 20009). Menurut WHO 2009 dari $70 \%$ penderita hipertensi yang terdeteksi hanya 25\% mendapatan pengobatan, 12,5\% diobati dengan baik (WHO, 2013) diprediksikan sampai tahun 2025 hipertensi semakin bertambah mencapai $60 \%$ yang mempengaruhi 1,56 milyar penduduk dunia. Di Indonesia kejadian hipertensi tahun 2013 yaitu 26,5\%, sedangkan yang diketahui petugas kesehatan hanya sebesar 9,5\%. Keadaan ini menunjukkan belum terdiagnosisnya penyakit oleh pelayanan kesehatan (Kemenkes, 2011).

Kejadian penyakit darah tinggi di Indonesia masih tinggi sehingga menjadi masalah kesehatan di masyarakat. penyakit jantung dan penyakit pembuluh darah merupakan factor resiko yang diakbtakn oleh hipertensi. Hipertensi jarang menunjukkan gejala, sehingga baru disadari bila telah menyebabkan terganggunya organ jantung. hipertensi sering ditemukan dengan tidak sengaja pada waktu pemeriksaan kesehatan rutin (Depkes RI, 2010).

\section{Metode Penelitian}

Penelitian ini merupakan deskriptif kuantitatif dengan memakai design cross sectional non analitik. Teknik sampling dalam peneltian ini yaitu total sampling. Jumlah sampel yaitu 32 orang. Instrument dalam penelitian ini instrument yang digunakan adalah tensimeter dan lembar observasi tekanan darah.

\section{Hasil dan Pembahasan}

A. Hasil Penelitian

1. Tabel 1 distribusi responden berdasarkan usia

\begin{tabular}{ccc}
\hline Usia & Jumlah & Prosentase \\
\hline 46-50 Tahun & 4 & 12,5 \\
50-55 Tahun & 6 & 15,625 \\
56-60 Tahun & 10 & 31,25 \\
61-65 Tahun & 8 & 25 \\
66-70 Tahun & 5 & 15,625 \\
\hline Total & 32 & 100
\end{tabular}

Tabel 1 menunjukkan usia responden mayoristas berada pada usia 56-60 tahun sebanyak 10 orang (31,25\%). Menurut Hasil penelitian Budi dkk (2011) tekanan darah hubungan dengan umur lansia (60 tahun).
Banyaknya penderita hipertensi berbanding lurus dengan umur yang bertambah karena perubahan bentuk pembuluh vaskuler besar menjadi lebih sempit dan kaku sehingga tekanan darah sistolik meningkat (Rahajeng dan Tuminah, 2009)

2. Tabel 2 distribusi responden berdasarkan jenis kelamin

\begin{tabular}{ccc}
\hline Jenis kelamin & Jumlah & Presentase \\
\hline Perempuan & 18 & 56,25 \\
Laki-laki & 14 & 43,75 \\
\hline Total & 32 & 100 \\
\hline
\end{tabular}

Tabel 2 menunjukkan jenis kelamin responden mayoristas perempuan sebanyak 18 orang (56,25\%). Menurut Singalingging (2011) rata-rata perempuan setelah usia 45 tahun akan mengalami peningkatan resiko hipertensi. Wanita yang belum belum menopause kadar hormon estrogen dapat membantu menambah kadar (HDL) High Density Lipoprotein. Kadar kolesterol HDL rendah dan tingginya kolesterol LDL mempengaruhi terjadinya proses aterosklerosis (Anggraini dkk, 2009).

3. Tabel 3 distribusi responden berdasrakan penyakit keturunan hipertensi

\begin{tabular}{ccc}
\hline Penyakit keturunan & Jumlah & Presentase \\
\hline Ya & 23 & 71,87 \\
Tidak & 9 & 28,13 \\
\hline Total & 32 & 100
\end{tabular}

Tabel 3 menunjukkan responden mayoritas menderita penyakit keturunan hipertensi sebanyak 23 orang (71,87\%). Hasil penelitian ini senada dengan hasil penelitian Irza (2009) didapatkan hasil bahwa faktor riwayat keluarga sangat berpengaruh terhadap kemungkinan terjadinya hipertensi.

4. Tabel 3 distribusi responden berdasarkan kebiasaan konsumsi garam Konsumsi

\begin{tabular}{|c|c|c|}
\hline Garam & Jumlah & Prosentase \\
\hline 1-2x perminggu & 6 & 18,75 \\
\hline $3-6 x$ perminggu & 14 & 43,75 \\
\hline 1x perhari & 7 & 21,875 \\
\hline$>1 \mathrm{x}$ perhari & 5 & 15,625 \\
\hline Total & 32 & 100 \\
\hline Tabel 4 & injukkar & responden \\
\hline mayoristas & asumsi & garam $3-6 x$ \\
\hline
\end{tabular}


perminggu sebanyak 14 responden (43,75\%). Sulchan (2012) mengungkapkan bahwa asupan tinggi natrium berresiko sebesar 7,9 kali terhadap hipertensi. Irza (2009) menyatakan bahwa faktor konsumsi natrium ada hubungan dengan hipertensi 5. Tabel 5 Gambaran tekanan darah dengan hasil penelitian yaitu rata-rata tekanan sistolik dan diastolik orang yang sering menkonsumsi makanan tinggi garam (seperti mie instan, ikan asin, kecap asin, keju dan saus tomat).

\begin{tabular}{ccccc}
\hline \multirow{2}{*}{ Klasifikasi } & \multicolumn{2}{c}{ Tekanan Darah } & \multirow{2}{*}{ Jumlah } & \multirow{2}{*}{ Prosentase } \\
\cline { 2 - 3 } & Sistolik & Diastolic & & \\
\hline Pra Hipertensi & $120-139 \mathrm{mmHg}$ & $80-89 \mathrm{mmHg}$ & 3 & 9,37 \\
Hipertensi Derajat I & $140-159 \mathrm{mmHg}$ & $90-99 \mathrm{~mm} \mathrm{Hg}$ & 18 & 56,25 \\
Hipertensi derajat II & $>160 \mathrm{mmHg}$ & $>100 \mathrm{mmHg}$ & 11 & 34,38 \\
\hline & Total & 32 & 100 \\
\hline
\end{tabular}

Tabel 5 menunjukkan responden mayoritas memiliki tekanan darah 140-159 mmHg atau Hipertensi Derajat I sebanyak 18 responden (56,25\%). Berdasarkan hasil penelitian gambaran tekanan darah pada responden di Desa Karanganyar berada pada Klasifikasi Hipertensi Derajat I (tekanan darah 140-159 mmHg) dengan rata-rata usia responden adalah lansia (5660 tahun), hasil ini sejalan dengan penelitian anbarasan (2015) tentang distribusi frekuensi penyakit hipertensi di puskesmas Rendang yaitu hipertensi grade I sebanyak 26 orang (43.3\%). hipertensi grade II sebanyak 34 kasus (56.7\%) yang sampelnya adalah orang yang sudah lanjut usia (lansia). Penelitian yasinta 2015 yaiu tekanan darah 60 responden berada pada tekanan darah sistolik rata-rata $147,75 \pm 15,85 \mathrm{mmHg}$ dan rata-rata tekanan darah diastolik yaitu $87,5 \pm 6,92 \mathrm{mmHg}$ tergolong pada hipertensi derajat I. Penelitian Douma di Yunani didapatkan hasil tingginya kejadian hipertensi lansia mencapai $89 \%$ dan bertambahnya umur maka kejadian penyakit hipertensi juga bertambah.

Sejalan dengan penelitian dperoleh hasil bahwa hipertensi menempati $87 \%$ kasus pada orang yang usianya lebih dari 60 tahun. National Healthand Nutrition Examination Survey (NHANES) menjelaskan bahwa $65 \%$ orang yang berumur diatas 65 tahun menderita hipertensi. Penelitian Dewhurst (2013) di Tanzania, yaitu kejadian penyakit hipertensi lansia cukup tinggi mencapai 69.9\% dari 2223 lansia. Stockslager (2008) menjelaskan jika meningkatnya penyakit hipertensi karena bertambahnya usia. sejalan dengan penelitian dimana hipertensi menempati 87\% kasus pada orang yang berusia diatas 60 tahun. Menurut Manuel (2001) tekanan darah sistolik dan diastolik meningkat setelah usia bertambah. Hasil Penelitian Aisyiah (2009) terdapat hubungan factor usia dengan kejadian hipertensi dan resiko hipertensi meningkat siring bertambahnya usia.

NHANES menjelaskan jika 65\% orang diatas usia 65 tahun terjangkit penyakit hipertensi. Penyakit ini dimulai dengan penyumbatan pembuluh darah, pembuluh darah menjadi kaku yang disertai dengan penyempitan dan pembesaran plague yang menghambat gangguan peredaran darah perifer. kelambanan aliran darah menyebabkan beratnya beban kerja jantung yang memberikan gambaran peningkatan tekanan darah dalam sistem sirkulasi (Yogiantoro, 2009). kejadian ini terjadi akibat pada lansia akan kehilangan kelanturan pembuluh darah menjadi kaku sedangkan jantung dipaksa memompa darah melalui pembuluh darah yang sempit sehingga berakibat naiknya tekanan darah (Sigarlaki, 2006).

Kesimpulan dan Saran

1. Kesimpulan

Status tekanan darah penderita hipertensi di Desa Kanganyar Kecamatan Kalianget sebagian besar yaitu hipertensi derajat I

2. Saran

a. Pelayanan kesehatan harus bekerjasama dengan lintas sektor yang terdekat untuk meningkatkan upaya deteksi dini serta penyuluhan hipertensi

b. Bagi penderita hipertensi agar berhatihati jika sudah berusia ( $>35$ tahun), karena mulai rentan terhadap hipertensi, lakukanlah pemeriksaan 
tekanan darah secara rutin minimal sebulan sekali.

c. Perlunya penelitian selanjutnya dengan metode berbeda dan jumlah sampel yang lebih banyak.

\section{Daftar Pustaka}

Aisyiah, Farida Nur. 2009. Faktor Resiko hipertensi pada empat kabupaten/Kota dengan prevalensi hipertensi tertinggi di Jawa dan Sumatera. Skripsi.IPB

Anbarasan, S. S. (2015). Gambaran Kualitas Hidup Lansia Dengan Hipertensi Di Wilayah Kerja Puskesmas Rendang Pada Periode 27 Februari Sampai 14 Maret 2015. Intisari Sains Medis, 4(1), 113-124.

Anggraini, AD., Waren, S., Situmorang, E., Asputra, H., dan Siahaan, SS. 2009. Faktor--Faktor Yang Berhubungan Dengan Kejadian Hipertensi Pada Pasien Yang Berobat Di Poliklinik Dewasa Puskesmas Bangkinang Periode Januari Sampai Juni 2008.Fakultas Kesehatan. Universitas Riau. Files of DrsMed-FK UNRI : 141Awal. Journal of Nutrition College, No. 1, Tahun 2012.

Budi, Ls., Sulchan, HM., Wardani, RS. 2011. Beberapa Faktor yang Berhubungan dengan Tekanan Darah pada Usia Lanjut di RW VIII Kelurahan Krobokan Kecamatan Semarang Barat Kota Semarang. Abstrak. Fakultas Kesehatan Masyarakat Universitas

Departemen Kesehatan RI. Data Pasien Hipertensi di Indonesia. 2001. http://www.depkes.go.id/index.php/ berita/press-release/263-hindarihipertensi

Dewhurst M, Dewhurst F, Gray W, Chaote P, Orega G, Walker W. The high prevalence of hypertekanan darahon in rural-dwelling Tanzanian older adults and the disparity between detection, treatment and control: a rule of sixths. Journal of Human Hypertension. 2013;27: 374- 380.

Bungo Tanjung, Sumatera Barat. Skripsi. Universitas Sumatera Utara.Karo SK. 2012. Hipertensi adalah Masalah Kesehatan Masyarakat. Dalam: Rilantono LI (penyunting). "Penyakit Kardovaskular (PKV) 5 Rahasia" selected reading, hlm. 235-248.
Jakarta. Badan Penerbit Fakultas Kedokteran Universitas Indonesia.

Irza, Syukraini. 2009. Analisis Faktor Resiko Hipertensi pada Masyarakat Nagari

Kementrian Kesehatan Republik Indonesia (2011) Profil Kesehatan Indonesia.2010 Jakarta Kementrian Kesehatan Republik Indonesia 2011 [Diakses pada 12 Januari 2016]. Available from URL: HIPERLINK http://www.depkes.go.id/downloads / PROFIL_DATA_KESEHATAN_INDO NESIA.pdf

Rahajeng, E., Tuminah, S. 2009. Prevalensi Hipertensi dan Determinannya di Indonesia. Majalah Kedokteran Indonesia. 59(12):580- 587Setyanda, Y. O. G., Sulastri, D., \& Lestari, Y. (2015). Hubungan merokok dengan kejadian hipertensi pada laki-laki usia 35-65 tahun di Kota Padang. Jurnal kesehatan andalas, 4(2).

Sigarlaki, HJO. 2006. Karakteristik Dan Faktor Berhubungan Dengan Hipertensi Di Desa Bocor, Kecamatan Bulus Pesantren, Kabupaten Kebumen, Jawa Tengah, Tahun 2006. Makara, Kesehatan. 10 (2): 78-88

Singalingging, G. 2011. Karakteristik Penderita Hipertensi Di Rumah Sakit Umum Herna Medan 2011. Medan : 16.

Stockslager, J.L., Schaeffer, L. (2008). Asuhan Keperawatan Geriatric. Edisi 2. Jakarta: EGC

Sulchan, Muhammad, Vindy Destiany. 2012. Asupan Tinggi Natrium dan LamaMenonton TV Sebagai Faktor Risiko Hipertensi Obeistik pada Remaja

World Health organization (WHO). (2013). A global brief on Hypertension. Silent killer, Global Public Health Crisis. World Health Organization.World Health Day 2013.(http://apps.who.int/iris/bitstr eam/10665/79059/1/WHO_DCO_WH D_2013.2_eng.pdf

Yogiantoro, M., 2009. Hipertensi Esensial. In: Sudoyo, A.W., et al eds. Buku Ajar Ilmu Penyakit Dalam 5th ed. Jilid II. Jakarta: Interna Publishing, 10791085. 